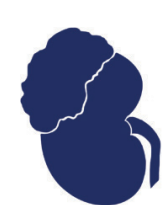

jkcvhl.com

WILMS TUMOR: NEPHROBLASTOMA

\title{
Genetic Polymorphisms of the TGFB1 Signal Peptide and Promoter Region: Role in Wilms Tumor Susceptibility?
}

\author{
Cintya Mayumi Ishibashi ${ }^{1}$, Carlos Eduardo Coral de Oliveira ${ }^{1}$, Roberta Losi Guembarovski ${ }^{1}$, Bruna \\ Karina Banin Hirata1, Glauco Akelinghton Freire Vitiello1, Alda Losi Guembarovski³, Marla Karine \\ Amarante $^{1}$, Karen Brajão de Oliveira ${ }^{1}$, Marina Okuyama Kishima ${ }^{3}$, Carolina Batista Ariza², Maria \\ Angelica Ehara Watanabe ${ }^{1}$
}

${ }^{1}$ Department of Pathological Sciences, State University of Londrina, Parana, Brazil; ${ }^{2}$ Department of Biology, State University of Londrina, Parana, Brazil; ${ }^{3}$ Department of Pathology, Clinical and Toxicological Analysis, Health Science Center, State University of Londrina, Londrina, Parana, Brazil.

\begin{abstract}
The aim of the present study was to investigate the rs1800468 (G-800A), rs1800469 (C-509T), rs1800470 (C29T), and rs1800471 (G74C) TGFB1 genetic polymorphisms and their haplotype structures in patients with Wilms Tumor (WT) and neoplasia-free controls. The genomic DNA was extracted from 35 WT patients and 160 neoplasia-free children, and the TGFB1 polymorphisms were genotyped by polymerase chain reaction, followed by restriction fragment length polymorphism. The haplotype structures were inferred, and permutation and logistic regression tests were performed to check for differences in haplotype distribution between the control and WT individuals. Positive associations were found in the recessive model for rs $1800469 \mathrm{~T}$ allele (OR: 8.417; 95\% CI: 3.177 to 22.297 ; P < 0.001) and for the rs $1800470 \mathrm{C}$ allele (OR: 3.000 ; $95 \%$ CI: 1.296 to $6.944 ; \mathrm{P}=0.01)$. Haplotype analysis revealed a significant negative association between GCTG and WT (OR: $0.236,95 \%$ CI: 0.105 to $0.534 ; \mathrm{P}=0.0002)$; by contrast, the GTTG haplotype was associated with increased risk for WT (OR: $12.0 ; 95 \%$ CI: 4.202 to 34.270 ; P < 0.001). Furthermore, rs 1800469 was negatively correlated with tumor size and a trend toward a positive correlation for capsular invasion was observed in the dominant model (Tau-b: $-0.43, \mathrm{P}=0.02$ and tau-b: $0.5, \mathrm{P}=0.06$, respectively). This is the first study with rs $1800468, \mathrm{rs} 1800469$, rs1800470, and rs1800471 TGFB1 polymorphisms in WT, and our results suggest that the TGFB1 promoter and signal peptide region polymorphisms may be associated with WT susceptibility and clinical presentation.
\end{abstract}

Keywords: genetic polymorphism; nephroblastoma; prognosis; susceptibility; TGFB1; Wilms tumor

Received: 7 April 2021; Accepted after revision: 19 August 2021; Published: 16 October 2021

Author for correspondence: Marla Karine Amarante, Laboratory DNA Polymorphisms and Immunology, Department of Pathological Sciences, Biological Sciences Center, State University of Londrina, PR445, Km 380 Celso Garcia Cid highway, Londrina, Brazil. Email: marlakarineuel@ gmail.com

How to cite: Ishibashi CM, \& Amarante, CK. Genetic Polymorphisms of the TGFB1 Signal Peptide and Promoter Region: Role in Wilms Tumor Susceptibility?. J Kidney Cancer VHL. 2021; 8(4): 22-31.

Doi: https://doi.org/10.15586/jkcvhl.v8i4.182

Copyright: Ishibashi CM and Amarante MK

License: This open access article is licensed under Creative Commons Attribution 4.0 International (CC BY 4.0). http://creativecommons.org/ licenses/by/4.0 


\section{Introduction}

Wilms tumor (WT), or nephroblastoma, is a childhood kidney cancer originated from the pluripotent embryonic kidney precursor (1) and consists histologically of smooth stromal, epithelial, and undifferentiated mesenchymal cells (2). It is the most common pediatric kidney tumor, affecting 1:10,000 children (3).

The incidence of this disease is increased in low-income countries, which also present the lowest survival rates for this disease. Therefore, there is a need for accurate and comprehensive records for the appropriate allocation of resources in order to improve the outcome for this curable childhood malignancy (4).

The survival rate in patients has increased considerably in recent decades to more than about $90 \%$ for localized disease and to over $70 \%$ for metastatic disease (5). However, despite a good response to therapy and high success rates, there are concerns due to the risk of irreparable side effects (6), as it targets cells with a high proliferative rate and the tumor affects tissues still in development (7). Furthermore, the prognostic indicators of recurrence and mortality are the disease stage and tumor histology, and the most significant unfavorable factors are the advanced stage and the presence of anaplasia, especially in the diffuse form, which is highly resistant to chemotherapy (8). Thus, improving our knowledge of tumor biology and biomarker identification may help to promote risk stratification and to introduce new targeted therapies that could minimize toxicity and enhance outcomes for patients with WT with unfavorable prognosis (6).

The tumor microenvironment is dynamic and its interaction with tumor cells is essential for cancer development, influencing growth, invasiveness, and metastatic process (9). In this context, transforming growth factor beta 1 (TGF $\beta 1$ ) is a pleiotropic cytokine that plays an important role in embryogenesis (10) and in physiological and pathological contexts by interfering with the cell cycle, apoptosis, and differentiation, also playing important roles in carcinogenic processes (11).

In normal and preneoplastic cells, TGF $\beta 1$ acts as a tumor suppressor associated with antiproliferative activity and apoptosis, but in advanced cancer stages, it acts as a tumor progression mediator (12). In malignant cells and at advanced stages of carcinogenesis, TGF $\beta 1$ promotes cell growth and epithelial-mesenchymal transition (EMT), which increase the invasiveness of these cells. In addition, it acts in the extracellular matrix remodeling and in immune system cells, inducing immunosuppression by generating regulatory $\mathrm{T}$ cells, anergy, and effector T-cells senescence, and angiogenesis through endothelial and smooth muscle cell activation, which favor the metastatic process (11).

In addition, it has been demonstrated that TGF $\beta 1$ regulates WT 1 gene (WTl) expression (13), a transcription factor necessary for kidney (14), gonads, and adrenal glands development (15). Also, its expression was found in a wide range of adult tumor types, such as colorectal cancer (16), lung cancer (17), and leukemia $(18,19)$.

There are also challenging aspects in WT evaluation, in relation to current and future markers of biological behavior with prognostic significance (20). Many polymorphisms have been reported in the TGFB1 gene (21) including rs1800468 (G-800A, c. $\left.-1638 \mathrm{G}>\mathrm{A}, \mathrm{c} .{ }^{*} 18 \mathrm{G}>\mathrm{A}\right)$ and $\mathrm{rs} 1800469$ (C-509T, c. $-1347 \mathrm{~T}>\mathrm{C}, \mathrm{c} . * 309 \mathrm{~T}>\mathrm{C})$ in the promoter region and rs1800470 (c.29C>T, Leu10Pro, T869C) and rs1800471 (c.74G $>$ C, Arg25Pro) in the signal peptide region that have been the most widely studied due to their potential functional implications on the dynamics of TGF $\beta 1$ expression and secretion. These polymorphisms have been associated with diverse cancers, including gastric cancer (22), esophageal squamous cell carcinoma (23), and breast cancer (BC) (24). Overall, results are controversial in the literature, varying according to cancer types and even among molecular subtypes and disease stage within tumor groups $(24,25)$. However, they have not yet been studied in WT pathogenesis.

Therefore, the aim of this study was to verify the genotype frequencies of TGFB1 rs1800468, 1800469, 1800470, and 1800471 , and their haplotype structures in WT patients and neoplasia-free controls in a Brazilian population.

\section{Materials and Methods}

\section{Human subjects}

The present study was approved by the Institutional Human Research Ethics Committee of Londrina State University, Paraná, Brazil (CAAE 73557317000005231). The form granting free and informed consent was signed by the parents of all the children and adolescents, and we also obtained the consent of those patients with decision-making ability to participate in the project. The WT samples consisted of 35 archived paraffin-embedded tumor tissues from child patients from the North of Paraná Laboratory of Anatomopathology and Cytology (Micropar) and the Laboratory of Pathology of the University Hospital of Londrina State University. Of these, $14(40 \%)$ were males and $21(60 \%)$ were females. Tumor staging distribution was $7(29 \%), 6(25 \%)$, $4(16.7 \%), 6(25 \%)$, and $1(4.2 \%)$ for stages I, II, III, IV, and $\mathrm{V}$, respectively (information was missing for 11 patients). Patients' age ranged from 1 to 13 years (median: 3 ).

The control group consisted of 160 samples from neoplasia-free healthy children or young adults, which included 124 blood samples and 36 buccal cell samples collected in University Hospital of Londrina State University. Among the control group, 77 (48.1\%) patients were male and $83(51.9 \%)$ were female, and the control group age ranged from 3 months to 19 years (median: 12). 


\section{DNA extraction}

DNA from the control group was obtained from peripheral white blood cells using a Mini Spin extraction kit (Biometrix, Curitiba, Brazil), following the manufacturer's instructions, and, in some cases, the DNA was obtained from buccal cells using a protocol based on the use of ammonium acetate (26). In the WT group, genomic DNA was isolated from formalinfixed, paraffin-embedded tissues using the innuPREP DNA Mini Kit (Analytik Jena AG, Jena, Germany), following the manufacturer's instructions. All DNA samples were quantified by NanoDrop 2000® Spectrophotometer (NanoDrop Technologies, Wilmington, USA) at 260nm wavelength, and the absorbance ratio at $260 / 280 \mathrm{~nm}$ was used to assess protein contamination in DNA samples.

\section{Genetic polymorphisms genotyping}

Genetic polymorphisms were analyzed by polymerase chain reaction (PCR), followed by Restriction Fragment Length Polymorphism (RFLP) analysis, as described by Jin et al. (27), with modifications. All PCR amplicons and restriction fragments were analyzed by electrophoresis in acrylamide gels (10\%), detected by silver staining.

The TGFB1 regions encompassing polymorphisms (promoter and signal peptide regions) were amplified using the same reaction condition, $4 \mathrm{ng} / \mu \mathrm{L}$ of DNA, $1 \times$ high fidelity PCR buffer, $1 \mathrm{mM} \mathrm{MgSO}{ }_{4}, 0.2 \mu \mathrm{M}$ primers, $0.13 \mathrm{mM}$ dNTP, and 1 U Platinum ${ }^{\mathrm{TM}}$ Taq DNA polymerase High Fidelity. All PCR reagents were purchased from Invitrogen ${ }^{\mathrm{TM}}$ (Carlsbad, CA, USA).

For the promoter region polymorphisms (rs1800468 and rs1800469), the primer sequences were 5'-GCAGTTGGCGAGAACAGTTG-3' and 5'-CCAGAACGGAAGGAGAGTCAG-3'. The PCR conditions were $10 \mathrm{~min}$ at $94^{\circ} \mathrm{C}$, 35 cycles of $45 \mathrm{~s}$ at $94^{\circ} \mathrm{C}, 1 \mathrm{~min}$ at $59^{\circ} \mathrm{C}$ and $1 \mathrm{~min}$ and $15 \mathrm{~s}$ at $72^{\circ} \mathrm{C}$, and $10 \mathrm{~min}$ at $72^{\circ} \mathrm{C}$. For the rs 1800468 genotype analysis, PCR products $(597 \mathrm{bp})$ were subjected to enzymatic digestion by HpyCH4IV (New England Biolabs ${ }^{\circledR}$, Ipswich, USA) and the genotype profiles were GG (402 bp and $195 \mathrm{bp}$ ), GA (597 bp, $402 \mathrm{bp}$, and $195 \mathrm{bp}$ ), and AA (597 bp). For the rs1800469 genotype analysis, PCR products (597 bp) were subjected to digestion by Bsu36I (New England Biolabs $\left.{ }^{\circledR}\right)$ and the genotype profiles were CC (488 bp and 109 bp), CT (597 bp, 488 bp, and 109 bp), and TT (597 bp).

Primer sequences for the signal peptide region (rs1800470 and rs1800471) were: 5'-TTCCCTCGAGGCCCTCCTA-3' and 5'-GCCGCAGCTTGGACAGGATC-3' and PCR conditions were $10 \mathrm{~min}$ at $96^{\circ} \mathrm{C}, 35$ cycles of $75 \mathrm{~s}$ at $96^{\circ} \mathrm{C}, 75 \mathrm{~s}$ at $62^{\circ} \mathrm{C}$ and $75 \mathrm{~s}$ at $73^{\circ} \mathrm{C}$, and $5 \mathrm{~min}$ at $73^{\circ} \mathrm{C}$. For the rs 1800470 polymorphism, PCR products (294 bp) were subjected to enzymatic digestion by MspAII (New England Biolabs ${ }^{\circledR}$ ) and the genotypes were CC (149 bp, $67 \mathrm{bp}, 40 \mathrm{bp}, 26 \mathrm{bp}$, and 12 bp), CT (161 bp, 149 bp, 67 bp, 40 bp, and 26 bp), and TT (161 bp, $67 \mathrm{bp}, 40 \mathrm{bp}$, and $26 \mathrm{bp}$ ). For the rs1800471 polymorphism, PCR products (294 bp) were subjected to enzymatic digestion by $B g l I$ (New England Biolabs $\AA$ ) and the genotype profiles were GG (131 bp, $103 \mathrm{bp}$, and $60 \mathrm{bp}$ ), GC (163 bp, 131 bp, 103 bp, and 60 bp), and CC (163 bp and 131 bp) (Figure 1).

To confirm the primers' specificity used in the present study, some PCR products for both TGFBl regions were purified using the PureLink ${ }^{\mathrm{TM}}$ PCR Purification Kit (Invitrogen, Cashland, USA) following the manufacturer's instructions and sequenced. The sequencing reaction was performed using the BigDye ${ }^{\circledR}$ Terminator v3.1 Cycle Sequencing Kit (Applied Biosystems ${ }^{\circledR}$, Foster City, USA). The amplicons were sequenced in a 24-capillary $3500 \times 1$ Genetic Analyzer (Applied Biosystems $\AA$ ). The resulting sequences revealed identity with GenBank NG_013364.1 (TGFB1) confirming primer specificity for all polymorphisms.

\section{Statistical analyses}

The case-control study for WT susceptibility was performed by the Odds Ratio (OR) calculus, adopting an estimate of the relative risk at $95 \%$ confidence intervals (CI), and Fisher's exact test. Genotypic (variant homozygotes or heterozygotes versus wild homozygotes), dominant (variant homozygotes and heterozygotes versus wild homozygotes), and recessive (variant homozygotes versus heterozygotes and wild homozygotes) models were tested for all individual polymorphisms. Correlation analyses between the polymorphisms and WT clinicopathological features were assessed by the Kendall's tau-b rank correlation coefficient. The TGFB1 haplotypes were determined using PHASE software version 2.1.1 (28) using all the study participants' genotypes, and the software was used to perform permutation tests to check the difference among haplotype distributions between the control and WT individuals. All other statistical analyses were performed in IBM $^{\circledR}$ SPSS $^{\circledR}$ Statistics 24.0 software (IBM ${ }^{\circledR}$, Armonk, New York, USA). All tests were two-tailed with a significance level set at 0.05 .

\section{Results}

Case-control association studies were conducted to determine the possible influence of polymorphisms on WT susceptibility. The genotype frequencies and case-control analyses for the promoter region (rs1800468 and rs1800469) and signal peptide (rs1800470 and rs1800471) polymorphisms are shown in Tables 1 and 2, respectively. The genotype frequencies for these polymorphisms in the control group were consistent with an independent control sample collected from the same geographical region (24). 
(A)
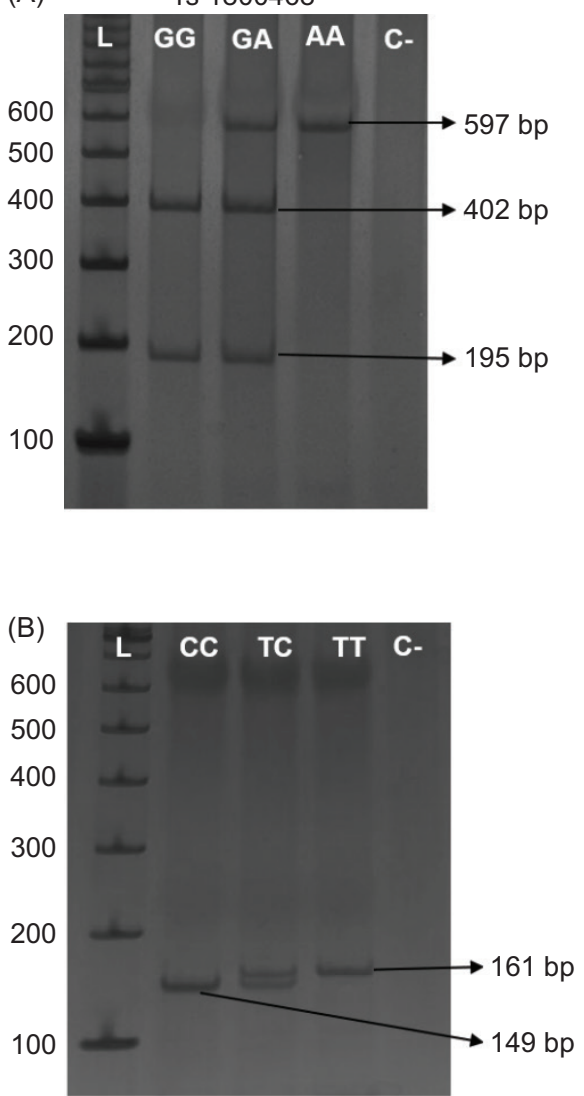

(C)
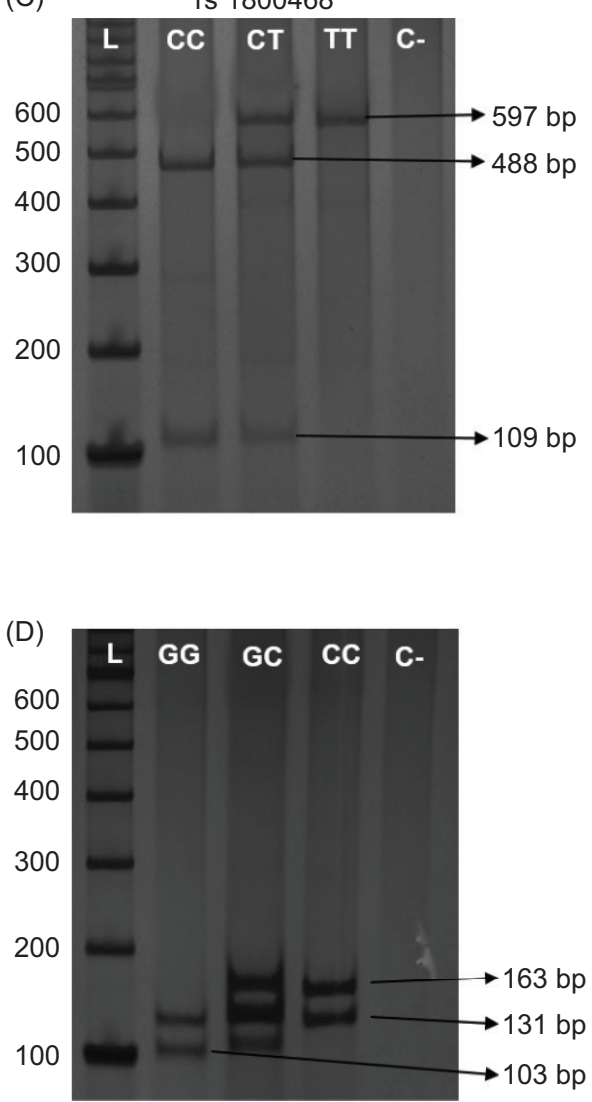

Figure 1: Promoter and signal peptide regions of TGFB1 genetic polymorphisms profile. Electrophoretic profile of: (A) rs1800468 (G-800A), (B) rs1800469 (C-509T), (C) rs1800470 (c.29C>T), and (D) rs1800471 (c.74G>C). The PCR products after restriction digestion were analyzed by electrophoresis on acrylamide gel (10\%), detected by silver staining method. L: Ladder $100 \mathrm{bp}$; C: negative control.

For the TGFB1 promoter region polymorphisms, the case-control study indicated no significant association for the rs1800468 polymorphism. However, the rs1800469 polymorphism presented a positive association for the $\mathrm{T}$ allele in the recessive model (OR: 8.417; 95\% CI: 3.177 to 22.297 ; $\mathrm{P}<$ 0.001) (Table 1).

Similarly, when the TGFB1 signal peptide polymorphisms were analyzed, a significant association was found for the rs1800470 polymorphism with increased risk for WT in the recessive model (OR: 3.000; 95\% CI: 1.296 to 6.944 ; $\mathrm{P}=0.01$ ). However, no significant association was found for the rs1800471 polymorphism (Table 2). For this polymorphism, analysis evaluating the $\mathrm{CC}$ genotype was not possible due to the absence of this genotype in the control group.

Correlation between polymorphisms and clinicopathological features were analyzed considering additive, dominant, and recessive models. A negative correlation was observed between tumor size $(\leq 8 \mathrm{~cm}$ vs $>8 \mathrm{~cm})$ and $\mathrm{rs} 1800469$ in the dominant model (Tau-b $=-0.43 ; \mathrm{P}=0.02$; Table 3). Furthermore, the lack of statistical significance in the positive correlation between this model and capsular invasion was only marginal (Tau-b $=0.5 ; \mathrm{P}=0.06$; Table 3 ). No other significant correlation was observed for any variant analyzed.

Twenty-two WT samples that could be genotyped for the four polymorphisms were included for haplotype analysis. Nine possible inferred haplotypes were observed (Table 4). A significant difference among the controls and patients with WT was observed $(\mathrm{P}=0.001)$ in global haplotype distribution (Table 4). Based on these results, a case-control study of the association of individual haplotype structures indicated that the GCTG haplotype conferred protection against tumor development (OR: $0.236 ; 95 \% \mathrm{CI}$ : 0.105 to $0.534 ; \mathrm{P}=0.0002)$ and GTTG was associated with risk (OR: 12.000; 95\% CI: 4.202 to 34.270; P < 0.0001) (Table 4). For this analysis, each haplotype structure was compared to the total number of haplotypes in the group, and the ACCC and 
Table 1: Genotypic frequencies in WT and control patients and case-control study for TGFB1 promoter region polymorphisms (rs1800468 and rs1800469).

\begin{tabular}{|c|c|c|c|c|c|}
\hline Models & Controls [n (\%)] & Patients [n (\%)] & Odds ratio & $95 \% \mathrm{CI}$ & $P$ value \\
\hline \multicolumn{6}{|l|}{ rs1800468 } \\
\hline GG & $105(92.1)$ & $26(92.8)$ & Reference & - & - \\
\hline GA & $7(6.1)$ & $1(3.6)$ & 0.577 & $0.068-4.898$ & 0.577 \\
\hline $\mathrm{AA}$ & $2(1.8)$ & $1(3.6)$ & 2.019 & $0.176-23.133$ & 0.572 \\
\hline \multicolumn{6}{|c|}{ Dominant model } \\
\hline GG & $105(92.1)$ & $26(92.8)$ & Reference & - & - \\
\hline $\mathrm{AA}+\mathrm{GA}$ & $9(7.9)$ & $2(7.2)$ & 0.897 & $0.183-4.406$ & 0.894 \\
\hline \multicolumn{6}{|c|}{ Recessive model } \\
\hline $\mathrm{GG}+\mathrm{GA}$ & $112(98.2)$ & $27(96.4)$ & Reference & - & - \\
\hline AA & $2(1.8)$ & $1(3.6)$ & 2.074 & $0.181-23.724$ & 0.557 \\
\hline \multicolumn{6}{|l|}{ rs1800469 } \\
\hline $\mathrm{CC}$ & $43(37.7)$ & $6(24.0)$ & Reference & - & - \\
\hline $\mathrm{CT}$ & $58(50.9)$ & $6(24.0)$ & 0.741 & $0.224-2.457$ & 0.625 \\
\hline $\mathrm{TT}$ & $13(11.4)$ & $13(52.0)$ & 7.167 & $2.271-22.615$ & $<0.001 *$ \\
\hline \multicolumn{6}{|c|}{ Dominant model } \\
\hline $\mathrm{CC}$ & $43(37.7)$ & $6(24.0)$ & Reference & - & - \\
\hline $\mathrm{TT}+\mathrm{CT}$ & $71(62.3)$ & $19(76.0)$ & 1.918 & $0.711-5.176$ & 0.199 \\
\hline \multicolumn{6}{|c|}{ Recessive model } \\
\hline $\mathrm{CC}+\mathrm{CT}$ & $101(88.6)$ & $12(48.0)$ & Reference & - & - \\
\hline $\mathrm{TT}$ & $13(11.4)$ & $13(52.0)$ & 8.417 & $3.177-22.297$ & $<0.001 *$ \\
\hline
\end{tabular}

CI: confidence interval. Fisher's exact test. *Significant $(\mathrm{P}<0.05)$.

ATCG haplotype structures were not considered due to their absence in the control group.

\section{Discussion}

WT is a neoplasm of embryonic origin whose structures and composition recapitulate characteristics of normal nephrogenesis (29). Failures during embryogenesis are considered as the causes of WT (1). In this context, studies have demonstrated the crucial role of the TGF $\beta 1$ in metanephric development during the fetal period (10), as well as in immunomodulation by inhibiting the activity of essential immune cells for the antitumor response. Thus, it is reasonable to assume that TGF $\beta 1$ also participates in WT development (30).
In the present study, we investigated four polymorphisms in TGFB1, two in the promoter region (rs1800468 and rs1800469) and two in the signal peptide region (rs1800470 and rs1800471), that are somehow involved in expression regulation and secretion of this cytokine, in relation to WT susceptibility.

Despite numerous studies describing a role for TGF $\beta 1$ in various neoplasms $(22,31)$, only two have demonstrated the direct participation of this cytokine in WT, associating TGF $\beta 1$ expression in tumor microenvironment invasion and disease progression (32), and showing that TGF $\beta 1$ signaling is the most important coordinator of anaplastic histology (33). However, studies on WT and genetic polymorphisms are even more scarce, and this is the first study evidencing these TGFB1 polymorphisms in this disease. 
Table 2: Genotypic frequencies in WT and control patients and case-control study for TGFB1 signal peptide region polymorphisms (rs1800470 and rs1800471).

\begin{tabular}{|c|c|c|c|c|c|}
\hline Models & Controls [n (\%)] & Patients [n (\%)] & Odds ratio & $95 \%$ CI & $P$ value \\
\hline \multicolumn{6}{|c|}{ rs1800470 } \\
\hline TT & $24(16.7)$ & $12(37.5)$ & Reference & - & - \\
\hline $\mathrm{TC}$ & $83(57.6)$ & $11(34.4)$ & 0.545 & $0.208-1.426$ & 0.216 \\
\hline $\mathrm{CC}$ & $37(25.7)$ & $9(28.1)$ & 2.056 & $0.752-5.618$ & 0.160 \\
\hline \multicolumn{6}{|c|}{ Dominant model } \\
\hline $\mathrm{TT}$ & $24(16.7)$ & $12(37.5)$ & Reference & - & - \\
\hline $\mathrm{CC}+\mathrm{TC}$ & $120(83.3)$ & $20(62.5)$ & 0.884 & $0.375-2.081$ & 0.777 \\
\hline \multicolumn{6}{|c|}{ Recessive model } \\
\hline $\mathrm{TT}+\mathrm{TC}$ & $107(74.3)$ & $23(71.9)$ & Reference & - & - \\
\hline $\mathrm{CC}$ & $37(25.7)$ & $9(28.1)$ & 3.000 & $1.296-6.944$ & $0.01 *$ \\
\hline \multicolumn{6}{|c|}{ rs1800471 } \\
\hline GG & $130(90.3)$ & $26(81.2)$ & Reference & - & - \\
\hline GC & $14(9.7)$ & $3(9.4)$ & 1.071 & $0.287-3.995$ & 0.918 \\
\hline $\mathrm{CC}$ & - & $3(9.4)$ & NA & NA & NA \\
\hline \multicolumn{6}{|c|}{ Dominant model } \\
\hline GG & $130(90.3)$ & $26(81.2)$ & Reference & - & - \\
\hline $\mathrm{CC}+\mathrm{GC}$ & $14(9.7)$ & $6(18.8)$ & 2.143 & $0.754-6.093$ & 0.153 \\
\hline
\end{tabular}

CI: confidence interval; Fisher's exact test; *Significant $(\mathrm{P}<0.05)$; NA: not available.

In this study, no association was found for the rs 1800468 polymorphism of the TGFB1 promoter region. Although no studies have evaluated this polymorphism in WT, some studies on other tumors have demonstrated increased risk associated with the A allele, such as BC (34) and uterine cervical cancer (35), while others failed to observe any significant association $(24,27)$.

Nevertheless, when the rs1800469 TGFB1 polymorphism was analyzed, the T allele was associated with WT susceptibility in the recessive model. While Jin, Deng (23), in a study on esophageal squamous cell carcinoma, have found association of the same variant with protection against cancer, studies on BC $(24,34)$ differently have shown an association of rs1800469 $\mathrm{T}$ allele with the risk of cancer.

The TGFB1 rs1800469 polymorphism is located in a Yin Yang 1 (YY1) transcription factor consensus-binding site. Studies using transient transfection analysis with promoterreporter constructs showed that the exchange from $\mathrm{C}$ to $\mathrm{T}$ at the -509 position of the promoter region could increase affinity for YY1 (36). This may be one of the mechanisms that leads to increased cytokine secretion in cancer patients' plasma, as observed in cases of pancreatic cancer (31), gastric cancer (22), as well as in cases of WT with poor prognosis (32).

For the signal peptide region, it was verified that the rs $1800470 \mathrm{C}$ allele was associated with WT development, in a recessive model. Similar results were found for other tumors, in which homozygous CC was associated with BC (37) and colorectal cancer (38) susceptibility.

Significant effect of rs1800470 polymorphism on the TGF $\beta 1$ secretion may provide an explanation for the reported associations with a variety of diseases, such as that of the present study. This polymorphism results in the exchange of a leucine $(\mathrm{T})$ for a proline $(\mathrm{C})$ at signal peptide amino acid 10, and it has been reported previously that the amount of TGF $\beta 1$ in serum is higher for $\mathrm{CC}$ homozygotes than TT homozygotes (39). Dunning, Ellis et al. (37), in a transfection study of HeLa cells with constructs encoding either the $\mathrm{C}$ or $\mathrm{T}$ allele of $T G F B 1$, indicated that the signal peptide with the $\mathrm{C}$ allele causes a 2.8 -fold increase in 
Table 3: Correlation analyses between TGFB1 rs1800469 and WT patient's clinicopathological features.

\begin{tabular}{|c|c|c|c|c|c|c|}
\hline \multirow[t]{2}{*}{ Parameter } & \multicolumn{3}{|c|}{ C-509T genotypes [n (\%)] } & \multicolumn{3}{|c|}{ Models (Tau-b; P) } \\
\hline & $\mathrm{CC}$ & CT & TT & Additive & Dominant & Recessive \\
\hline \multicolumn{7}{|l|}{ Tumor size } \\
\hline$\leq 8 \mathrm{~cm}$ & $0(0.0)$ & $3(60.0)$ & $2(40.0)$ & $-0.12 ; 0.61$ & $-0.43 ; 0.02 *$ & $0.09 ; 0.71$ \\
\hline$>8 \mathrm{~cm}$ & $4(40.0)$ & $1(10.0)$ & $5(50.0)$ & & & \\
\hline \multicolumn{7}{|c|}{ Capsular invasion } \\
\hline Absent & $3(60.0)$ & $0(0.0)$ & $2(40.0)$ & $0.405 ; 0.13$ & $0.50 ; 0.06$ & $0.35 ; 0.20$ \\
\hline Present & $1(12.5)$ & $1(12.5)$ & $6(75.0)$ & & & \\
\hline \multicolumn{7}{|c|}{ Nodal involvement } \\
\hline Absent & $3(37.5)$ & $1(12.5)$ & $4(50.0)$ & $-0.07 ; 0.77$ & $0.04 ; 0.87$ & $-0.17 ; 0.52$ \\
\hline Present & $2(33.3)$ & $2(33.3)$ & $2(33.3)$ & & & \\
\hline \multicolumn{7}{|c|}{ Distant metastasis } \\
\hline Absent & $1(33.3)$ & $1(33.3)$ & $1(33.3)$ & $0.00 ; 1.00$ & $0.00 ; 1.00$ & $0.00 ; 1.00$ \\
\hline Present & $2(33.3)$ & $2(33.3)$ & $2(33.3)$ & & & \\
\hline
\end{tabular}

*Significant $(\mathrm{P}<0.05)$.

Table 4: Case-control association study for haplotype structures.

\begin{tabular}{|l|c|c|c|c|}
\hline Haplotype structure & Control [n (\%)] & WT [n (\%)] & Odds ratio (CI) & NA value \\
\hline ACCC & $0(0.0)$ & $1(2.3)$ & $0.437(0.055-3.509)$ & 0.694 \\
\hline ACTG & $10(5.0)$ & $1(2.3)$ & NA & - \\
\hline ATCG & $0(0.0)$ & $1(2.3)$ & $1.049(0.212-5.206)$ & 1.000 \\
\hline GCCC & $7(3.5)$ & $2(4.6)$ & $0.506(0.111-2.297)$ & 0.534 \\
\hline GCCG & $14(7.1)$ & $8(18.2)$ & $0.236(0.105-0.534)$ & $<0.001 *$ \\
\hline GCTG & $96(48.5)$ & $1(2.3)$ & $1.512(0.153-14.890)$ & 0.554 \\
\hline GTCC & $3(1.5)$ & $16(36.4)$ & $1.253(0.635-2.484)$ & 0.593 \\
\hline GTCG & $62(31.3)$ & $12(27.3)$ & $12.000(4.202-34.270)$ & $<0.001 *$ \\
\hline GTTG & $6(3.0)$ & & & -
\end{tabular}

CI: confidence interval. NA: not analyzed. *Significant $(\mathrm{P}<0.05)$ through permutation analysis (for global haplotype distribution) or Fisher's exact test (for odds ratio).

secretion compared with the $\mathrm{T}$ allele form. This may reflect structure and property changes in the TGF $\beta 1$ signal peptide due to the substitution of amino acids.

Susianti, Handono (40) showed that the presence of proline amino acid (allele $\mathrm{C}$ ) changes the hydrophobic core region of the TGF $\beta 1$ signal peptide and breaks the $\alpha$-helix structure favored by leucine (allele T), altering the stability of the signal peptide interaction with the Signal Recognition Particle (SRP) and translocation complex in endoplasmic reticulum, reducing the values on transmembrane tendency, and stabilizing protein partner binding. As the sequence of the signal peptide is responsible for allowing the export of new proteins to endoplasmic reticulum lumen and then secretion, such changes could modify the exportation 
and secretion dynamics, with consequent cytokine-level alteration.

It is therefore plausible that TGF $\beta 1$ local secretion by tumors and/or local stromal cells is also higher for $\mathrm{CC}$ homozygotes. As noted earlier, current hypotheses on the effects of TGF $\beta 1$ on tumor development suggest that increased amounts of this cytokine activity may suppress the early stages of tumor development but promote the invasiveness, metastasis, and angiogenesis of advanced tumors (37). In this context, Zhang, Liu (32) reported that TGF $\beta 1$ expression in WT tissues was associated with invasion/metastasis, confirmed by an invasion assay through transiently transfected TGFB1 to primary WT cells.

Moreover, Hamatani et al. (13) verified that long-term TGF $\beta 1$ stimulation altered the methylation pattern of regulatory regions and decreased $W T 1$ expression in a human podocyte cell line. The WT1 protein is a transcription factor, which plays multiple roles in development, including kidney development, tissue homeostasis, and disease (41). WT1 was initially discovered as a tumor suppressor in WT (42) and the first gene found to be inactivated in WT (1). Our results indicated the association of two TGFB1 polymorphisms, which lead to increased cytokine secretion, with the development of WT. As observed by Hamatani et al. (13), overexpression of TGF $\beta 1$ leads to under expression of WT1, and this could be a mechanism involved in WT development.

In this study, no association was found between rs1800471 signal peptide polymorphism and WT susceptibility, as described in bladder (43) and colorectal adenoma cancers (38).

In clinicopathological analyses, rs1800469 in the dominant model indicated smaller tumor size and a trend toward a positive correlation was shown for capsular invasion. This might indicate the potential action in TGF $\beta 1$ cytostatic effect in controlling cell proliferation but mediating EMT and invasion, as previously reported in WT (30, $32,33)$. The dysregulation of TGFB $\beta$ has been linked to the initiation and progression of multiple human cancers, including WT (44).

Several diseases have been found at higher frequencies in individuals with haplotypes of certain genes, but there are no studies on WT. The TGFBI haplotype association analysis revealed that the GCTG structure conferred protection against WT while the GTTG haplotype, which differs only by rs 1800469 , confers risk. Although the individual C allele of rs 1800470 polymorphism conferred risk for WT, this was not observed in the haplotype analysis, perhaps due to the small number of samples included in the haplotype analysis (22 samples). Moreover, here we showed a positive association for the $\mathrm{T}$ allele (rs1800469) and $\mathrm{C}$ allele (rs1800470) with WT susceptibility, although a larger number of samples is necessary to confirm this potential association.
Few studies have performed a haplotype analysis of TGFB1 polymorphisms. Jin, Hemminki (27) conducted an analysis with the same four TGFBI polymorphisms (promoter and signal peptide regions) but no associations with $\mathrm{BC}$ were found; on the other hand, our group has showed subtype-specific associations between TGFB1 haplotypes and $\mathrm{BC}$ risk (24). Berndt et al. (38), in a study with five TGFB1 polymorphisms (rs1800468, rs1800469, rs1800470, rs1800471, and rs1800472), found an association of the GTCGC haplotype structure with susceptibility to colorectal adenoma, which is partially compatible with our individual polymorphism analysis, where the T allele of rs1800469 (C-509T) and C allele of rs1800470 (T869C) polymorphism conferred risk for WT.

\section{Conclusion}

This is the first study with the rs1800468, rs1800469, rs1800470, and rs1800471 TGFB1 polymorphisms in WT patients, and our results suggest that the rs1800469 and rs1800470 polymorphisms may serve as markers associated with the susceptibility and clinical presentation of this disease.

\section{References}

1. Rivera MN, Haber DA. Wilms' tumour: Connecting tumorigenesis and organ development in the kidney. Nat Rev Cancer. 2005;5(9):699-712. http://dx.doi.org/10.1038/nrc1696

2. Akpa MM, Iglesias D, Chu L, Thiebaut A, Jentoft I, Hammond $\mathrm{L}$, et al. Wilms tumor suppressor, WT1, cooperates with microRNA-26a and microRNA-101 to suppress translation of the polycomb protein, EZH2, in mesenchymal stem cells. J Biol Chem. 2016;291(8):3785-95. http://dx.doi.org/10.1074/jbc. M115.678029

3. Royer-Pokora B. Genetics of pediatric renal tumors. Pediatr Nephrol. 2013;28(1):13-23. http://dx.doi.org/10.1007/s00467012-2146-4

4. Cunningham ME, Klug TD, Nuchtern JG, Chintagumpala MM, Venkatramani R, Lubega $J$, et al. Global disparities in Wilms tumor. J Surg Res. 2020;247:34-51. http://dx.doi. org/10.1016/j.jss.2019.10.044

5. Pritchard-Jones K. Controversies and advances in the management of Wilms' tumour. Arch Dis Childhood. 2002;87(3):241-4. http://dx.doi.org/10.1136/adc.87.3.241

6. Maturu P. The inflammatory microenvironment in Wilms tumors. In: van den Heuvel-Eibrink MM, editor. Wilms tumor. Brisbane; 2016. http://dx.doi.org/10.15586/codon.wt.2016.ch12

7. Duffner PK, Cohen ME, Parker MS. Prospective intellectual testing in children with brain tumors. Ann Neurol. 1988;23(6):575-9. http://dx.doi.org/10.1002/ana.410230608

8. Dome JS, Cotton CA, Perlman EJ, Breslow NE, Kalapurakal JA, Ritchey ML, et al. Treatment of anaplastic histology Wilms' tumor: Results from the fifth national Wilms' tumor study. J Clin Oncol. 2006;24(15):2352-8. http://dx.doi.org/10.1200/ JCO.2005.04.7852 
9. Yaqub S, Aandahl EM. Inflammation versus adaptive immunity in cancer pathogenesis. Crit Rev Oncog. 2009;15(1-2):43-63. http://dx.doi.org/10.1615/CritRevOncog.v15.i1-2.20

10. Bush KT, Sakurai H, Steer DL, Leonard MO, Sampogna RV, Meyer TN, et al. TGF-beta superfamily members modulate growth, branching, shaping, and patterning of the ureteric bud. Dev Biol. 2004;266(2):285-98. http://dx.doi.org/10.1016/j. ydbio.2003.10.023

11. Fontoura BM, Blobel G, Yaseen NR. The nucleoporin Nup98 is a site for GDP/GTP exchange on ran and termination of karyopherin beta 2-mediated nuclear import. J Biol Chem. 2000;275(40):31289-96. http://dx.doi.org/10.1074/jbc. M004651200

12. Kubiczkova L, Sedlarikova L, Hajek R, Sevcikova S. TGFbeta - An excellent servant but a bad master. J Transl Med. 2012;10:183. http://dx.doi.org/10.1186/1479-5876-10-183

13. Hamatani H, Sakairi T, Ikeuchi H, Kaneko Y, Maeshima A, Nojima Y, et al. TGF-betal alters DNA methylation levels in promoter and enhancer regions of the WT1 gene in human podocytes. Nephrology. 2019;24(5):575-84. http://dx.doi. org/10.1111/nep.13411

14. Fanni D, Fanos V, Monga G, Gerosa C, Locci A, Nemolato S, et al. Expression of WT1 during normal human kidney development. J Matern Fetal Neonatal Med. 2011;24(Suppl 2):44-7. http://dx.doi.org/10.3109/14767058.2011.606619

15. Bandiera R, Sacco S, Vidal VP, Chaboissier MC, Schedl A. Steroidogenic organ development and homeostasis: A WT1centric view. Mol Cell Endocrinol. 2015;408:145-55. http://dx. doi.org/10.1016/j.mce.2015.01.009

16. Aslan A, Erdem H, Celik MA, Sahin A, Cankaya S. Investigation of insulin-like growth factor-1 (IGF-1), P53, and Wilms' tumor 1 (WT1) expression levels in the colon polyp subtypes in colon cancer. Med Sci Monit. 2019;25:5510-17. http:// dx.doi.org/10.12659/MSM.915335

17. Wang X, Gao P, Lin F, Long M, Weng Y, Ouyang Y, et al. Wilms' tumour suppressor gene 1 (WT1) is involved in the carcinogenesis of lung cancer through interaction with PI3K/ Akt pathway. Cancer Cell Int. 2013;13(1):114. http://dx.doi. org/10.1186/1475-2867-13-114

18. Cilloni D, Gottardi E, De Micheli D, Serra A, Volpe G, Messa F, et al. Quantitative assessment of WT1 expression by real time quantitative PCR may be a useful tool for monitoring minimal residual disease in acute leukemia patients. Leukemia. 2002;16(10):2115-21. http://dx.doi.org/10.1038/sj.leu.2402675

19. Sakaguchi AY, Amarante MK, Oliveira CECd, Hiroki CH, Trigo FC, Watanabe MAE. Transforming growth factor beta 1: Possible involvement with acute lymphoblastic leukemia prognosis in pediatric patients. Clin Oncol Res. 2020;6. http://dx.doi. org/10.31487/j.COR.2020.09.11

20. Parsons LN. Wilms tumor: Challenges and newcomers in prognosis. Surg Pathol Clin. 2020;13(4):683-93. http://dx.doi. org/10.1016/j.path.2020.08.007

21. Martelossi Cebinelli GC, Paiva Trugilo K, Badaro Garcia S, Brajao de Oliveira K. TGF-betal functional polymorphisms: A review. Eur Cytokine Netw. 2016;27(4):81-9. http://dx.doi. org/10.1684/ecn.2016.0382

22. Choi YJ, Kim N, Shin A, Lee HS, Nam RH, Chang H, et al. Influence of TGFB1 C-509T polymorphism on gastric cancer risk associated with TGF-betal expression in the gastric mucosa. Gastric Cancer. 2015;18(3):526-37. http://dx.doi. org/10.1007/s10120-014-0412-9
23. Jin G, Deng Y, Miao R, Hu Z, Zhou Y, Tan Y, et al. TGFB1 and TGFBR2 functional polymorphisms and risk of esophageal squamous cell carcinoma: A case-control analysis in a Chinese population. J Cancer Res Clin Oncol. 2008;134(3):345-51. http://dx.doi.org/10.1007/s00432-007-0290-1

24. Vitiello GAF, Guembarovski RL, Hirata BKB, Amarante MK, de Oliveira CEC, de Oliveira KB, et al. Transforming growth factor beta 1 (TGF $\beta 1$ ) polymorphisms and haplotype structures have dual roles in breast cancer pathogenesis. J Cancer Res Clin Oncol. 2018;144(4):645-55. http://dx.doi.org/10.1007/ s00432-018-2585-9

25. Shin A. Genetic polymorphisms of the transforming growth factor-1 gene and breast cancer risk: A possible dual role at different cancer stages. Cancer Epidemiol Biomark Prevent. 2005;14(6):156770. http://dx.doi.org/10.1158/1055-9965.EPI-05-0078

26. Aidar M, Line SR. A simple and cost-effective protocol for DNA isolation from buccal epithelial cells. Braz Dent J. 2007;18(2):148-52. http://dx.doi.org/10.1590/S010364402007000200012

27. Jin Q, Hemminki K, Grzybowska E, Klaes R, Soderberg M, Zientek $\mathrm{H}$, et al. Polymorphisms and haplotype structures in genes for transforming growth factor betal and its receptors in familial and unselected breast cancers. Int $\mathrm{J}$ Cancer. 2004;112(1):94-9. http://dx.doi.org/10.1002/ijc.20370

28. Stephens M, Smith NJ, Donnelly P. A new statistical method for haplotype reconstruction from population data. Am J Hum Genet. 2001;68(4):978-89. http://dx.doi.org/10.1086/319501

29. Hohenstein P, Pritchard-Jones K, Charlton J. The yin and yang of kidney development and Wilms' tumors. Genes Dev. 2015;29(5):467-82. http://dx.doi.org/10.1101/gad.256396.114

30. Amarante MK, de Oliveira CEC, Ariza CB, Sakaguchi AY, Ishibashi CM, Watanabe MAE. The predictive value of transforming growth factor- $\beta$ in Wilms tumor immunopathogenesis. Int Rev Immunol. 2017;36(4):233-9. http://dx.doi.org/10.1080/0 8830185.2017 .1291639

31. Javle M, Li Y, Tan D, Dong X, Chang P, Kar S, et al. Biomarkers of TGF-beta signaling pathway and prognosis of pancreatic cancer. PLoS One. 2014;9(1):e85942. http://dx.doi.org/10.1371/ journal.pone.0085942

32. Zhang L, Liu W, Qin Y, Wu R. Expression of TGF-betal in Wilms' tumor was associated with invasiveness and disease progression. J Pediatr Urol. 2014;10(5):962-8. http://dx.doi. org/10.1016/j.jpurol.2014.01.010

33. Lu J, Tao Y-F, Li Z-H, Cao L, Hu S-Y, Wang N-N, et al. Analyzing the gene expression profile of anaplastic histology Wilms' tumor with real-time polymerase chain reaction arrays. Cancer Cell Int. 2015;15(1). http://dx.doi.org/10.1186/ s12935-015-0197-x

34. Parvizi S, Mohammadzadeh G, Karimi M, Noorbehbahani M, Jafary A. Effects of two common promoter polymorphisms of transforming growth factor-betal on breast cancer risks in Ahvaz, West South of Iran. Iranian J Cancer Prev. 2016;9(1):e5266. http://dx.doi.org/10.17795/ijcp-5266

35. Ramos-Flores C, Romero-Gutierrez T, Delgado-Enciso I, Maldonado GE, Plascencia VM, Vazquez-Vuelvas OF, et al. Polymorphisms in the genes related to angiogenesis are associated with uterine cervical cancer. Int $\mathbf{J}$ Gynecol Cancer. 2013;23(7):1198-204. http://dx.doi.org/10.1097/ IGC.0b013e31829f4c6f

36. Silverman ES, Palmer LJ, Subramaniam V, Hallock A, Mathew S, Vallone J, et al. Transforming growth factor-beta1 
promoter polymorphism C-509T is associated with asthma. Am J Respir Crit Care Med. 2004;169(2):214-19. http://dx.doi. org/10.1164/rccm.200307-973OC

37. Dunning AM, Ellis PD, McBride S, Kirschenlohr HL, Healey CS, Kemp PR, et al. A transforming growth factorbeta1 signal peptide variant increases secretion in vitro and is associated with increased incidence of invasive breast cancer. Cancer Res. 2003;63(10):2610-15.

38. Berndt SI, Huang WY, Chatterjee N, Yeager M, Welch R, Chanock SJ, et al. Transforming growth factor beta 1 (TGFB1) gene polymorphisms and risk of advanced colorectal adenoma. Carcinogenesis. 2007;28(9):1965-70. http://dx.doi.org/10.1093/ carcin/bgm 155

39. Grainger DJ, Heathcote K, Chiano M, Snieder H, Kemp PR, Metcalfe JC, et al. Genetic control of the circulating concentration of transforming growth factor type beta1. Hum Mol Genet. 1999;8(1):93-7. http://dx.doi.org/10.1093/hmg/8.1.93

40. 40. Susianti H, Handono K, Purnomo BB, Widodo N, Gunawan A, Kalim H. Changes to signal peptide and the level of transforming growth factor-beta1 due to T869C polymorphism of TGF betal associated with lupus renal fibrosis. SpringerPlus. 2014;3:514. http://dx.doi.org/10.1186/2193-1801-3-514

41. Hastie ND. Wilms' tumour 1 (WT1) in development, homeostasis and disease. Development. 2017;144(16):2862-72. http:// dx.doi.org/10.1242/dev.153163

42. Yang L, Han Y, Saurez Saiz F, Minden MD. A tumor suppressor and oncogene: The WT1 story. Leukemia. 2007;21(5):86876. http://dx.doi.org/10.1038/sj.leu.2404624

43. Gautam KA, Pooja S, Sankhwar SN, Sankhwar PL, Goel A, Rajender S. c.29C $>$ T polymorphism in the transforming growth factor-beta1 (TGFB1) gene correlates with increased risk of urinary bladder cancer. Cytokine. 2015;75(2):344-8. http://dx.doi. org/10.1016/j.cyto.2015.05.017

44. Shi Q, Wu H, Li Y, Shen L, Tian X, Lin T, et al. Inhibition of Wilms' tumor proliferation and invasion by blocking TGF-beta receptor I in the TGF-beta/Smad signaling pathway. BioMed Res Int. 2020;2020:8039840. http://dx.doi.org/10.1155/2020/8039840 